\title{
Factors Affecting Users' Acceptance of E-Billing System in Surakarta Tax Office
}

\author{
Rino Ardhian Nugroho', Arlyn Dewi Susilowati², \\ Okki Chandra Ambarwati ${ }^{3}$, and Arum Pratiwi ${ }^{4}$ \\ 1,2,3,4 Public Administration Department, Faculty of Social and Political Sciences, Universitas Sebelas Maret \\ Jln. Ir. Sutami No. 36A, Surakarta 57126, Indonesia \\ ${ }^{1}$ rino.nugroho@staff.uns.ac.id; 2arlyndewis@student.uns.ac.id; \\ 33okkiambarwati@student.uns.ac.id; ${ }^{4}$ arumpr07@student.uns.ac.id
}

Received: $30^{\text {th }}$ March 2018/ Revised: $9^{\text {th }}$ May 2018/ Accepted: $28^{\text {th }}$ May 2018

How to Cite: Nugroho, R. A., Susilowati, A. D., Ambarwati, O. C., \& Pratiwi, A. (2018).

Factors Affecting Users' Acceptance of E-Billing System in Surakarta Tax Office.

ComTech: Computer, Mathematics and Engineering Applications,9(1), 37-42. https://doi.org/10.21512/comtech.v9i1.4621

\begin{abstract}
This research aimed to analyze factors that affected the acceptance of e-billing system of Surakarta tax office with Unified Theory of Acceptance and Use of Technology (UTAUT) model. The survey was done on electronic billing (e-billing) system users in Surakarta. Partial Least Square-Structural Equation Modelling (PLSSEM) was used to analyze the users' intention in adopting e-billing system. The result indicates that two UTAUT variables (performance expectancy and social influence) affect the system usage significantly. Meanwhile, the other variables like effort expectancy and facilitating conditions do not affect e-billing system adoption in Indonesia.
\end{abstract}

Keywords: user acceptance, E-billing system, Unified Theory of Acceptance and Use of Technology (UTAUT), Partial Least Square-Structural Equation Modelling (PLSSEM)

\section{INTRODUCTION}

The development of information technology encourages the government to provide a better service to the public. Berdykhanova, Dehghantanha, and Hariraj (2010) explained that information technology usage, particularly the use of the Internet, improved the efficiency and effectiveness of government's internal operations and communication with the public. Electronic government (e-government) increasingly plays an important role to improve the quality of public services. One of the government offices that tries to apply the e-government through innovation and technology-based electronic services is the Directorate General of Taxes of the Ministry of Finance.

In the modern era, the demands for the innovation in government services have been prevalent. One of the innovations is the electronic billing (e-billing) system for the taxpayer. By using this system, the taxation system will be more effective and efficient in public services. Eventually, the easiness in paying taxes will improve the national income by accomplishing taxes target in a specific year (Pujiani, 2013).

Taxation is a major element in supporting Indonesia's economic development. According to Indonesian tax office website (Lubis, 2015), it supports approximately $70 \%$ of total government's income. This income supports the run of operation in government; and provides better public facilities and other related government activities. Looking at the numbers, it is obvious that the impact of taxation income is crucial for government's operation. Thus, it needs to be improved. Prior researches indicate that the modernization of taxation system will improve tax compliance and taxation administration, and high employee productivity will increase the government's income through taxes (Rahayu \& Lingga, 2011). One of the facilities of the e-system that recently implemented in Indonesia Tax Office is electronic billing (e-billing) system. E-billing is an Internet-based public service provided by the government to facilitate the payment of taxes (Yusup, Hardiyana, \& Sidharta, 2015). The use of e-billing has been deemed as mandatory by Indonesian Tax office since July 1st, 2016.

E-billing in this research can be regarded as part of the electronic government (e-government) as it is operated by the government. E-government has been implemented by the government to improve its effectiveness and efficiency. According to Kumar, Mukerji, Butt, and Persaud (2007), e-government refers to the delivery of information and services online from the government to the public via the Internet or other digital services. In addition, Winarno (2002) mentioned that e-government enabled the government to improve the quality of services to the public, improve its performance, and reduce corruption and other maladministration. Sabandi, Pambudi, and Sohidin (2009) mentioned that there were four relationships in e-government. Those were Government to Citizen (G2C), Government-to-Employee (G2E), Government to Business (G2B), and Government to Government (G2G).

Generally, e-government is divided into three main levels: publish, national interact, and transaction (Indrajit, 2002). In this research, the e-billing refers to e-government level three (transaction). It has two-way interactions between 
public and government. E-billing is electronic payment system (billing system) which facilitates taxpayers to pay the taxes more easily, quickly, and accurately. The benefits of e-billing are that the taxpayers can pay the taxes from anywhere and anytime and avoid errors in the recording of transactions (Yusup et al., 2015)

E-government is indispensable for the government modernization. Its success depends on the adoption or acceptance by the users (Khalil, 2014). As indicated by Wangpipatwong, Chutimaskul, and Papasratorn (2008), the government should consider the perception of the citizens against the website of e-government and explore the factors that significantly affect the desire of citizens to continue to use the website of e-government. However, understanding why communities accept or reject the e-billing becomes a challenge for the government. By understanding the factors and effects of users' acceptance can help the government to formulate appropriate measures to promote and improve the services of e-tax service (Wang, 2012). Therefore, to analyze what factors that affect the e-billing, this research will use the model of Unified Theory of Acceptance and Usage of Technology (UTAUT). It is a combination of several existing technology acceptance model.

UTAUT is one of the most recent technology acceptance model developed by Venkatesh, Morris, Davis, and Davis (2003). It is based on the theories of behavior in technology usage and acceptance of the technology. This model aims to explain the interest of users to use the system and usage behavior. It can be regarded as a model for assessing the adoption of new technologies and predicting the system acceptance among potential users. It combines several theories of technology acceptance. It is proven to be more successful than the other theories as it explains up to $70 \%$ of the user intention to use the new system. It consists of variables that predict users' decision on a technology adoption based on four independent variables. First, performance expectancy is the extent to which the system helps improve the work. Second, effort expectancy is the easiness level of technology usage. Third, social influence refers to the extent that social environment considers important to convince someone in adopting the technology. Last, facilitating condition means the availability of technical infrastructure in the organization. These variables are moderated by individual variables such as gender, age, experience, and voluntariness of use.

The theoretical framework in this research uses the dependent variables in the UTAUT model to see the factors that influence the users' acceptance of e-billing services in Indonesia. However, this research only uses the main determinant of moderating variables without researching using moderating variables in the UTAUT model. The reason for excluding moderating variables is based on the nature of the case study taken. Nugroho (2015) found that four moderating variables in the UTAUT were not relevant to be used in the context where the technology usage was mandatory. Considering this research has similar nature that e-billing is mandatory, all of those moderating variables are omitted.

Previous researches on e-billing adoption in Indonesia have indicated the significant relationship between perceived ease of use, perceived usefulness, and facilitating condition as the predictor of system use (Yusup, Hardiyana, \& Sidharta, 2015). This research will attest that finding by adopting similar variables into the model. The variables examined in this research are performance expectancy $(\mathrm{PE})$ that is similar to perceived usefulness, effort expectancy (EE) that is similar to the perceived ease of use, facilitating condition (FC), and social influence (SI) as independent variables. Then, system usage (SU) from the e-billing is the dependent variable. The relationship between each independent variable and the dependent variable is when users believe and feel the benefits. The benefits can be that by using the system of e-billing, it will improve their performance, the system can be used with ease, supportive facilities are available, and users get influences from the surrounding environment then it will affect the use of the system. Even though this research uses prior research result as predictors (Yusup et al., 2015), this research will not use the similar model to explain the relationship between variables. The researchers will propose a simpler model based on Nugroho (2015). The research framework is shown in Figure 1.

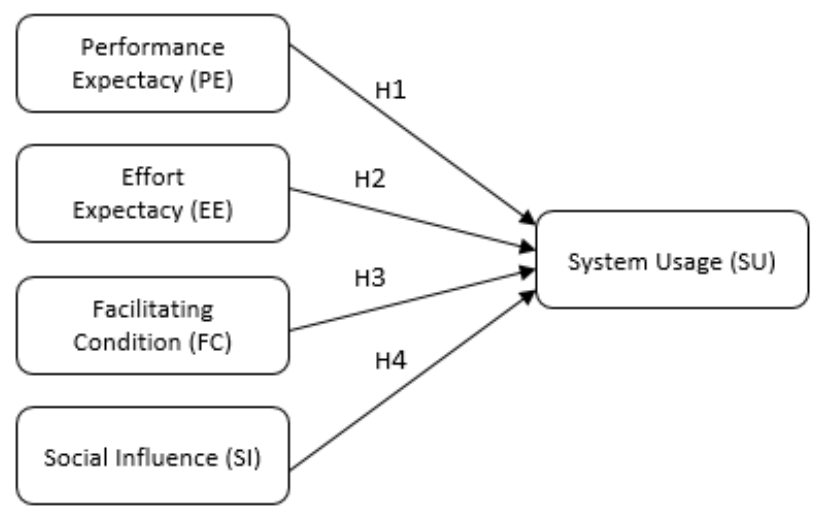

Figure 1 Research Framework (User Acceptance in E-Billing)

No matter how sophisticated an electronic government system is, it is useless if it is not accepted by the public. The success of e-government is affected by at least $20 \%$ of technology and $80 \%$ of human, process, and organization (United Nations, 2012). Human resources factors as users are vitally important in the new e-government system implementation. The level of acceptance of the user to use the new system determines the success or failure of these systems (Tangke, 2005). Therefore, understanding the factors that affect system acceptance can help the government to formulate appropriate measures to promote better e-billing services to the public (Wang, 2012). This article will analyze the factors affecting e-billing adoption. The understanding of those factors will enable Indonesian government to propose a policy for improving tax income. This research will be done in the e-billing system in Surakarta, Indonesia. The reason for choosing Indonesia is because Indonesian e-government is behind the other Southeast Asian Countries in the EGDI ranking (number 116). In addition, Surakarta is chosen because this city ranks 7 out of 8 cities in Central Java despite, although there are plenty of innovations in e-government system (kominfo. go.id). Therefore, doing research in this city may portray the reason for citizen's rejection to accept the e-billing system as part of e-government. Another reason for doing research in e-billing is this kind of research of e-billing in developing country has rarely been conducted, so the finding will fill the gap in the literature. Based on the research framework in Figure 1, the hypotheses are summarized in Table 1. 
Table 1 The Hypotheses Evaluated in the Research

\begin{tabular}{cl}
\hline Hypothesis & \multicolumn{1}{c}{ Description } \\
\hline H1 & $\begin{array}{l}\text { Performance Expectancy (PE) positively } \\
\text { affects the system usage of e-billing (SU) }\end{array}$ \\
H2 & $\begin{array}{l}\text { Effort Expectancy (EE) positively affects the } \\
\text { system usage of e-billing (SU) }\end{array}$ \\
H3 & $\begin{array}{l}\text { Facilitating Condition (FC) positively affects } \\
\text { the system usage of e-billing (SU) } \\
\text { H4 }\end{array}$ \\
& $\begin{array}{l}\text { Social Influence (SI) positively affects the } \\
\text { system usage of e-billing (SU) }\end{array}$ \\
\hline
\end{tabular}

\section{METHODS}

This research uses the quantitative approach to explains the causal relationships between research variables through hypothesis testing (Singarimbun \& Effendi, 2005). The methods used is a survey with convenience sampling technique. A group of people who have been using e-billing system in Surakarta tax office is chosen as the respondents. The number of minimum sample is 10 times the arrow heading toward dependent variables (Hair, Hult, Ringle, $\&$ Sarstedt 2014). In this research, there are 4 independent variables (PE, EE, FC, and $\mathrm{SI}$ ) toward 1 dependent variable (SU). Hence, the minimum sample required is 40 respondents. Because this research uses purposive sampling, generalization to the population will be carefully taken.

The questionnaire is given to taxpayers in Indonesian tax office in Surakarta that has been using e-billing to pay their tax. Questions in the survey are developed based on prior research in e-government adoption in Indonesia (Nugroho, 2015). The item questions used in this research can be seen in Appendix. Each indicator is measured by the five-point Likert scale ranging from 1 as strongly disagree (SD), 2 as disagree (D), 3 as neutral (N), 4 as agree (A), and 5 as strongly agree (SA).

Moreover, Partial Least Square-Structural Equation Modelling (PLS-SEM) is used as technical analysis tools. PLS-SEM is a powerful method of analysis because it does not assume a data normality and only needs relatively small number of samples (Hair et al., 2014). In this research, PLSSEM is used to predict the influence of the independent variable ( $\mathrm{x}$ ) to dependent variable (y) and explain the theoretical relationship between the two variables.

\section{RESULTS AND DISCUSSIONS}

The description of respondents can be divided into three categories. Those are gender, education level, and experience in using e-billing. There are 40 respondents in this research. Based on gender, $42 \%$ of them are men and the rest $(58 \%)$ is women. Respondents that dominates this survey is around $21-30$ years $(45 \%)$. It is followed by the respondents with age of 31-40 years (27\%), age of 41-50 years $(15 \%)$, age over 50 years $(8 \%)$, and age of $\leq 20$ years $(5 \%)$. Based on education level, the number of respondents graduated from high school is highest (48\%). Then, there are also respondents graduated from university/college (45\%), and junior high school (7\%). In the experience of using e-billing, the respondents are divided. Before it is mandatory (34\%) and after it is mandatory $(65 \%)$.
Prior to structuring the full model, a model evaluation procedure should be conducted. Tests of convergent and discriminant validity are used to ensure the validity of the instruments. Then, composite reliability is used to ensure the reliability (Hair et al., 2014).

Convergent validity with reflective indicators is measured based on outer loadings in each item. Items with outer loadings above 0,7 should be retained. However, those that are below 0,7 should be deleted (Hair et al., 2014). For the early stages of the research, the measurement value loading of 0,5 to 0,6 is considered quite good (Ghozali, 2014). All of the loadings in this research are above 0,7 , so no item is deleted based on convergent validity criteria. The result is in Table 2.

Moreover, discriminant validity of reflective indicators is evaluated according to the fact that each item should be loaded on itself, not to other items (Hair et al., 2014). Another evaluation is to assess the validity is look at the Average Variance Extracted (AVE) value. The value greater than 0,50 indicates validity of the model (Hair, 2014). Based on this criterion, FC1, SI3, SI5, and SI7 are deleted to improve the discriminant validity of the model. Table 2 summarizes the finding.

In addition to validity test, reliability test is conducted by using two criteria. Those are composite reliability and Cronbach's alpha. A variable is reliable if the values of composite reliability and Cronbach's alpha are above 0,70 (Hair et al., 2014; Ghozali, 2014). Based on the evaluation in Table 2, all of the items are retained because all items exceed 0,5 as the baseline number.

After the evaluation of the outer model already meets all the criteria, the further testing is conducted. Hypothesis testing is conducted based on PLS-SEM procedure. The $\mathrm{t}$-value of the test is compared with t-value in the t-table. In this research, the significance level of 0,05 is taken as the benchmark (Hair et al., 2014). The summary of hypothesis testing is presented in Table 3 .

Table 3 indicates that path coefficient from $\mathrm{PE}$ to $\mathrm{SU}$ is positive and significant at $0,05(\beta=0,328, \mathrm{p}=0,034)$. Hence, H1 is supported. Moreover, EE to SU is positive but insignificant at 0,05 level $(\beta=-0,025, p=0,871)$. Therefore, $\mathrm{H} 2$ is not supported.

Furthermore, path coefficient from $\mathrm{FC}$ to $\mathrm{SU}$ is positive and insignificant $(\beta=0,306, p=0,070)$. This result implies that $\mathrm{H} 3$ is not supported. Lastly, SI to $\mathrm{SU}$ is positive and significant $(\beta=0,371, p=0,037)$. It means $\mathrm{H} 4$ is supported. The model structuring is in Figure 2.

The structural model is evaluated by using the r-square $\left(\mathrm{R}^{2}\right)$, effect size $\left(\mathrm{f}^{2}\right)$, and prediction relevance $\left(\mathrm{Q}^{2}\right)$. The structural model which has $\mathrm{R}^{2}$ results above 0,83 , 0,67 , and 0,19 indicates that the model is good, moderate, and weak respectively (Hair et al., 2014; Ghozali, 2014). Based on the model structuring $\mathrm{R}^{2}=0,846$, it means that the independent variable of $\mathrm{PE}, \mathrm{EE}, \mathrm{FC}$, and SI can explain $84,6 \%$ of variations in SU. Only $15,4 \%$ of variations are explained by other variables that are not included in the model. This calculation indicates that the model proposed in this research is a good model as it is above 0,83 . In addition to $\mathrm{R}^{2}$, the structural model based on effect size $\left(\mathrm{f}^{2}\right)$ value needs to be evaluated. The value of $\mathrm{f}^{2}$ equals to 0,02 , 0,15 , or 0,35 . It can be interpreted whether the influence of predictor variable is weak, medium, or large (Hair et al., 2014; Ghozali, 2014).

Based on the $\mathrm{f}^{2}$ calculation, the effect size output of this research can be summarized. First, the effect sizes of $\mathrm{EE}\left(\mathrm{f}^{2}=0,001\right)$ and $\mathrm{FC}\left(\mathrm{f}^{2}=0,135\right)$ indicate that both $\mathrm{EE}$ and 
Table 2 Summary of Reflective Measurement Model in E-Billing Adoption

\begin{tabular}{|c|c|c|c|c|c|c|}
\hline Variable & Indicator & Loadings & $\begin{array}{l}\text { Composite } \\
\text { Reliability }\end{array}$ & $\begin{array}{c}\text { Cronbach's } \\
\text { Alpha }\end{array}$ & AVE & $\begin{array}{l}\text { Discriminant } \\
\text { Validity }\end{array}$ \\
\hline \multirow[t]{4}{*}{ Effort Expectancy (EE) } & EE1 & 0,744 & 0,914 & 0,887 & 0,641 & Yes \\
\hline & EE2 & 0,753 & & & & \\
\hline & EE3 & 0,856 & & & & \\
\hline & EE4 & 0,827 & & & & \\
\hline \multirow{5}{*}{$\begin{array}{l}\text { Facilitating Condition } \\
\text { (FC) }\end{array}$} & FCI* & 0,797 & 0,898 & 0,859 & 0,640 & Yes* \\
\hline & $\mathrm{FC} 2$ & 0,778 & & & & \\
\hline & FC3 & 0,811 & & & & \\
\hline & $\mathrm{FC} 4$ & 0,829 & & & & \\
\hline & FC5 & 0,783 & & & & \\
\hline \multirow{4}{*}{$\begin{array}{l}\text { Performance Expectancy } \\
(\mathrm{PE})\end{array}$} & PE1 & 0,808 & 0,929 & 0,913 & 0,621 & Yes* \\
\hline & PE2 & 0,830 & & & & \\
\hline & PE3 & 0,758 & & & & \\
\hline & PE4 & 0,754 & & & & \\
\hline \multirow[t]{5}{*}{ Social Influence (SI) } & $\mathrm{S} 11$ & 0,768 & 0,891 & 0,848 & 0,621 & Yes* \\
\hline & $\mathrm{S} 12$ & 0,765 & & & & \\
\hline & S13* & 0,812 & & & & \\
\hline & S14 & 0,820 & & & & \\
\hline & $\mathrm{S} 15^{*}$ & 0,852 & & & & \\
\hline \multirow[t]{3}{*}{ System Usage (SU) } & SU1 & 0,901 & 0,922 & 0,886 & 0,747 & Yes \\
\hline & SU2 & 0,860 & & & & \\
\hline & SU3 & 0,886 & & & & \\
\hline
\end{tabular}

*deleted to improve the discriminant validity

Table 3 Path Coefficient of the E-Billing Model

\begin{tabular}{cccccc}
\hline & Original Sample (O) & Sample Mean (M) & $\begin{array}{c}\text { Standar Deviation } \\
\text { (STDEV) }\end{array}$ & $\begin{array}{c}\text { T-Statistics } \\
\text { (O/STEDEV) }\end{array}$ & P-Values \\
\hline $\mathrm{PE} \rightarrow \mathrm{SU}$ & 0,328 & 0,371 & 0,154 & 2,125 & 0,034 \\
$\mathrm{EE} \rightarrow \mathrm{SU}$ & $-0,025$ & $-0,027$ & 0,153 & 0,162 & 0,871 \\
$\mathrm{FC} \rightarrow \mathrm{SU}$ & 0,306 & 0,304 & 0,169 & 1,813 & 0,070 \\
$\mathrm{SI} \rightarrow \mathrm{SU}$ & 0,371 & 0,336 & 0,177 & 2,094 & 0,037 \\
\hline
\end{tabular}

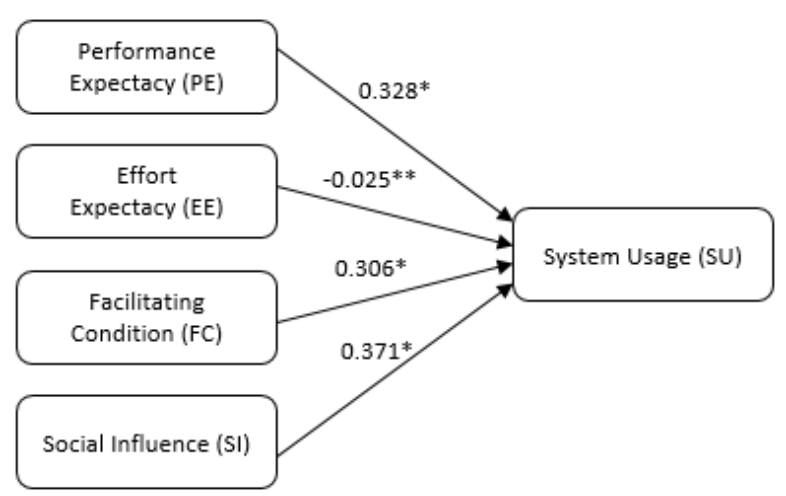

Figure 2 Model Structuring in User Acceptance in E-Billing 
FC have a weak influence in SU. Second, the two variables have the $\mathrm{f}^{2}$ of PE $(0,163)$ and SI $(0,263)$. These results show that PE and SI have a moderate effect on SU.

Furthermore, as a part of the model evaluation, the prediction relevance $\left(\mathrm{Q}^{2}\right)$ is also calculated using blindfolding procedure. The value of $\mathrm{Q}^{2}$ below 0 indicates that the models have less predictive relevance (Hair et al., 2014; Ghozali, 2014). The calculation of $\mathrm{Q}^{2}$ in this research is a value of 0,568 . This result shows that proposed model has the value of predictive relevance $\left(\mathrm{Q}^{2}\right)$ above 0 . It means that the ability of this model in predicting the dependent variable is good. These three criteria $\left(\mathrm{R}^{2}, \mathrm{f}^{2}\right.$, and $\left.\mathrm{Q}^{2}\right)$ shows that the proposed model has a good predictive capability. According to the hypothesis test and the modeling evaluation, it can be concluded that two out of four hypotheses are accepted. The hypothesis test is summarized in Table 4. PE and SI influence SU significantly. Meanwhile, EE and FC are not significant.

In Table 3, the value of the path coefficient of PE is 0,328 . It means there is a positive influence about $32,8 \%$ to SU. The result supports the research conducted by Ellyana, Redy, and Hamzah (2009), Azmi and Bee (2010) and Yusup et al. (2015). All of them found that the benefits expectation gave a positive effect on the use of electronic systems. Based on this result, a person will receive and use e-billing as they believe that the system can provide benefits towards their works. If e-billing enables time savings, improves effectiveness, efficiency, and transparency, taxpayers as the users will likely adopt it.

Based on hypothesis test, it can be seen that EE has no effect on SU. It means that taxpayers in Surakarta do not consider the effort of using the system as the factors of using or rejecting the e-billing system. They may not see that the easiness of the system operation is important in their decision to use an e-government system. The third hypothesis that tests the influence of FC on SU is also proven to be insignificant. Based on this finding, it can be said that availability of FC is not a concern for Surakarta taxpayers. They are not concerned with the condition of facilities such as the availability of technical support, training, and adequate infrastructure. This research supports the result by Ellyana et al. (2009). They suggested that the condition of the facilities did not have any influence towards someone's intention to use a system.

The last hypothesis (H4), it can be concluded that SI gives positive effect to SU. The value of path coefficient of $\mathrm{SI}$ on the SU is 0,371 . It means there is $37,1 \%$ of positive influence from SI to SU. This result supports prior research conducted by Khalil (2014), and Yusup et al. (2015). They found that SI affected a person's intentions to use the existing systems. This result is also in line with the argument of Ajzen and Fishbein (1980) who stated that an individual would be affected to use a system when other people and the environment around them used the same system.

The result on H4 indicates that influence of SI such as social pressure or coercion, the presence of other people who have used the system, the desire to follow others, and the image may affect taxpayers to use e-billing. The higher the influence given by others for users is, the higher the acceptance and use of a system will be. Moreover, the system will be increasingly accepted and used by the user, if there is more encouragement by others to use the system. In the context of Surakarta e-billing acceptance, the government should use the strategy of influencing social environment by encouraging more people to be involved in the system. By doing that, more people will adopt the e-billing system, and there are higher possibilities for people who refuse to use the system to adopt the system.

E-government success is not only because of the technical systems but also the acceptance of the system by the users. Previous researchers find that perception of the citizens will significantly affect the use of e-government services (Wangpipatwong et al., 2008) and the success of e-government system is determined by the user's acceptance (Khalil, 2014). Therefore, gaining the picture of citizen's perception of a system usage will improve the success of e-government system. As Ratminto and Winarsih (2007) mentioned, the public service quality was achieved when public expectations were met. If the government wants to improve service quality in tax collection, these two factors (PE and SI) as the basic expectation of citizens when adopting e-billing system should be considered. The government may also issue a regulation that coerces taxpayer to use e-billing and at the same time provides the benefit of e-billing system for the potential users.

Table 4 The Hypothesis Test Summary of E-Billing Adoption

\begin{tabular}{clcc}
\hline Hypothesis & \multicolumn{1}{c}{ Description } & Variable & Result \\
\hline H1 & $\begin{array}{l}\text { Performance Expectancy (PE) positively } \\
\text { affects the system usage of e-billing (SU) }\end{array}$ & PE $\rightarrow \mathrm{SU}$ & Accepted \\
$\mathrm{H} 2$ & $\begin{array}{l}\text { Effort Expectancy (EE) positively affects } \\
\text { the system usage of e-billing (SU) }\end{array}$ & $\mathrm{EE} \rightarrow \mathrm{SU}$ & Rejected \\
$\mathrm{H} 3$ & $\begin{array}{l}\text { Facilitating Condition (FC) positively } \\
\text { affects the system usage of e-billing (SU) }\end{array}$ & $\mathrm{FC} \rightarrow \mathrm{SU}$ & Rejected \\
& $\begin{array}{l}\text { Social Influence (SI) positively affects the } \\
\text { system usage of e-billing (SU) }\end{array}$ & SI $\rightarrow$ SU & Accepted \\
\hline
\end{tabular}




\section{CONCLUSIONS}

After the survey is conducted, the researchers find that two variables (PE and SI) influence the users' decision to adopt e-billing system significantly in Surakarta tax office.

Implications of this research can be divided into practical implication and suggestion for further research. Practically, this research suggests Surakarta government put more attention on giving information about the benefit of using e-billing from the perspective of users. This suggestion is based on the fact that PE is the significant predictor of e-billing SU in Surakarta tax office. Then, the government should do activities that may add the e-billing users. A coercive action such as putting e-billing as the only system for all tax billing transactions will motivate potential users to use e-billing system in Surakarta tax office. Moreover, a persuasive action may be taken as opposed to the coercive ones. Friendly advertising, quizzes, and another approach that may motivate users are advised. It is because the result indicates that SI is crucial in SU. The limitation of the research is the sampling size. Therefore, for further research, the researchers suggest to obtain more respondents to gain consistencies of the results. Random sampling strategy is also suggested for further research so that the result can be generalized into larger population. By adding respondents, this result may illustrate a larger population.

\section{REFERENCES}

Ajzen, I., \& Fishbein, M. (1980). Understanding attitudes and predicting social behaviour. Prentice-Hall.

Azmi, A. C., \& Bee, N. L. (2010). The acceptance of the e-filing system by Malaysian taxpayers: A simplified model. Electronic Journal of E-Government, 8(1), 13-22.

Berdykhanova, D., Dehghantanha, A., \& Hariraj, K. (2010). Trust challenges and issues of e-government: E-tax prospective. In 2010 International Symposium in Information Technology (ITSim) (Vol. 2, pp. 10151019).

Ellyana, D. D., Redy, A., \& Hamzah, A. (2009). Variabel anteseden dan konsekuensi pemanfaatan sistem informasi (Studi empiris pada pemerintahan kabupaten di pulau Madura). Jurnal Akuntansi dan Keuangan Indonesia, 6(1), 71-88.

Ghozali, I. (2014). Structural Equation Modeling: Metode alternatif dengan Partial Least Square (PLS) ( $4^{\text {th }} \mathrm{ed}$.). Semarang: Badan Penerbit Universitas Diponegoro.

Hair, Jr., J. F., Hult, G. T. M., Ringle, C. M, \& Sarstedt, M. (2014). A primer on Partial Least Squares Structural Equation Modeling (PLS-SEM). California: SAGE Publications.

Indrajit, R. E. (2002). Electronic government: Strategi pembangunan dan pengembangan sistem pelayanan publik berbasis teknologi digital. Andi.

Lubis, A. S. (2015). Publikasi artikel. Retrieved from https://bppk.kemenkeu.go.id/id/
Khalil, O. E. (2014). The adoption of the Traffic Violation E-Payment System (TVEPS) of Kuwait. Electronic Journal of E-Government, 12(1), 3-21.

Kumar, V., Mukerji, B., Butt, I., \& Persaud, A. (2007). Factors for successful e-government adoption: A conceptual framework. Electronic Journal of E-government, 5(1), 63-76.

Nugroho, R. A. (2015). Electronic government adoption in developing countries: The case of the Indonesian electronic procurement system ( $\mathrm{PhD}$ Thesis). The University of Queensland.

Pujiani, M. (2013). Analisis efektivitas penggunaan e-system terhadap penerimaan pajak di KPP Pratama Palembang Ilir Timur. Jurnal Akuntansi, 1-9.

Rahayu, S., \& Lingga, I. S. (2011). Pengaruh modernisasi sistem administrasi perpajakan terhadap kepatuhan wajib pajak (Survei atas wajib pajak badan pada KPP Pratama Bandung" X"). Jurnal Akuntansi, 1(2), 119.

Ratminto, \& Winarsih. (2007). Manajemen pelayanan: Pengembangan model konseptual, penerapan citizen's charter dan standar pelayanan minimal. Yogyakarta: Pustaka Pelajar.

Sabandi, M., Pambudi, D., \& Sohidin. (2009). Penerapan modifikasi model TAM guna peningkatan mutu layanan e-government pemerintah daerah melalui rekayasa sistem untuk mencapai good governance dan daya saing ekonomi lokal. Surakarta: LPPM UNS.

Singarimbun, M., \& Effendi. (2005). Metode penelitian survey. Jakarta: LP3ES.

Tangke, N. (2005). Analisa penerimaan penerapan Teknik Audit Berbantuan Komputer (TABK) dengan menggunakan Technology Acceptance Model (TAM) pada Badan Pemeriksa Keuangan (BPK) RI. Jurnal Akuntansi dan Keuangan, 6(1), 10-30.

United Nations. (2012). E-Government survey. Retrieved from https://publicadministration.un.org/egovkb/ Portals/egovkb/Documents/un/2012-Survey/ Complete-Survey.pdf

Venkatesh, V., Morris, M. G., Davis, G. B., \& Davis, F. D. (2003). User acceptance of information technology: Toward a unified view. MIS Quarterly, 27(3), 425478.

Wang, X. (2012). Factors influence citizen adoption for government e-tax service. Retrieved from http://oru. diva-portal.org/smash/record.jsf?pid=diva2:528165

Wangpipatwong, S., Chutimaskul, W., \& Papasratorn, B. (2008). Understanding citizen's continuance intention to use e-government website: A composite view of technology acceptance model and computer self-efficacy. Electronic Journal of E-Government, $6(1), 55-64$

Winarno, W. (2002). Sistem informasi manajemen. Yogyakarta: UPP STIM YKPN.

Yusup, M., Hardiyana, A., \& Sidharta, I. (2015). User acceptance model on e-billing adoption: A study of tax payment by government agencies. Asia Pacific Journal of Multidisciplinary Research, 3(4), 150157. 